\title{
Radioactive cesium contamination and its biological half-life in larvae of Stenopsyche marmorata (Trichoptera: Stenopsychidae)
}

\author{
Takeshi Fujino $^{1} \cdot$ Shota Kobori ${ }^{1} \cdot$ Takeshi Nomoto $^{2} \cdot$ Masaru Sakai $^{3} \cdot$ Takashi Gomi $^{4}$
}

Received: 3 August 2016 / Revised: 26 October 2017 / Accepted: 27 October 2017 / Published online: 18 December 2017

(c) The Author(s) 2017. This article is an open access publication

\begin{abstract}
The total radioactive Cs concentration in final-instar Stenopsyche marmorata larvae from the Mano River, Fukushima Prefecture, in 2013 was found to be $>1000 \mathrm{~Bq} \mathrm{~kg}^{-1}$ in dry weight. The concentration of radioactive Cs in the river water itself was on the order of $0.01 \mathrm{~Bq} \mathrm{~kg}^{-1}$, while its concentration in drifting fine particulate organic matter (FPOM) was on the order of $10,000 \mathrm{~Bq} \mathrm{~kg}^{-1}$ in dry weight. When excretion experiments were performed in the summer and winter, significant decreases in the Cs concentrations in the whole body of $S$. marmorata were observed in both seasons. The biological half-life of Cs-137 was 5.3 and $8.8 \mathrm{~h}$ for the nonwintering generation and the wintering generation, respectively. Another elimination test using a stable Cs solution was performed, and the Cs concentration was observed to decrease rapidly to $7.5 \%$ of its original level in the digestive tract of $S$. marmorata after $72 \mathrm{~h}$, but stable Cs remained in muscle and extra-alimentary tissue of $S$. marmorata. As the total radioactive Cs in the water was quite low, its concentration in S. marmorata from the Mano River reflects the fact that it feeds on FPOM. The radioactive Cs concentration in the FPOM significantly declined in 2015, but a corresponding decline was not observed for S. marmorata. We therefore infer that ultrafine particulate matter such as suspended vermiculite clay is strongly contaminated with radioactive Cs, and that this radioactive Cs passes continuously through the digestive tract of S. marmorata.
\end{abstract}

Keywords Biological half-life $\cdot$ Cs contamination $\cdot$ FPOM $\cdot$ S. marmorata

\section{Introduction}

Stenopsyche spp. (Trichoptera: Stenopsychidae) are widely distributed in gravel bed rivers in Asian countries (Dudgeon 1999; Tanida 2002; Nozaki et al. 2016). Due to their high individual biomass and high productivity compared with other trichopteran species, they have been used in the

Takeshi Fujino

fujino@mail.saitama-u.ac.jp

1 Department of Environmental Science and Technology, Saitama University, Saitama 338-8570, Japan

2 Civil Engineering and Eco-Technology Consultants Co., Ltd., Saitama 338-0851, Japan

3 Faculty of Science and Engineering, Chuo University, Tokyo 112-8551, Japan

4 Graduate School of Agriculture, Tokyo University of Agriculture and Technology, Fuchu, Tokyo 183-8509, Japan biomonitoring of various types of contamination, such as heavy metals released from industrial waste and microcystins from toxic algae (Tochimoto et al. 2000, 2003; Katagami et al. 2004; Aizawa et al. 2009; Matsuzaki 2011; Rainbow et al. 2012). Because the life cycle and variation in individual biomass of $S$. marmorata are well studied compared with those of other trichopteran species, it is common to investigate its fifth-instar larvae, which is the final and longest phase before the pupal stage (Gose 1970; Nishimura 1984; Aoya and Yokoyama 1987).

Since the Fukushima Dai-ichi Nuclear Power Plant (FDNPP) accident in March 2011, significant levels of radioactive cesium, Cs-134 and Cs-137, have been detected in (for example) freshwater fish, insects, leaves, sediment, and detritus in many Japanese rivers and streams. The Ministry of the Environment of Japan has published annual reports on radioactive-substance monitoring surveys for aquatic organisms. Among the various aquatic insects in river and lake waters investigated in this context, radioactive Cs was reported to be at its highest level in S. marmorata (Ministry 
of the Environment, Japan 2015). Although the level of radioactive $\mathrm{Cs}$ in river water has decreased to $0.01 \mathrm{~Bq} \mathrm{~L}^{-1}$ in most streams and rivers since 2012, a high level of radioactive Cs is still being detected in the larvae of Stenopsyche spp., which are sedentary and net-spinning filter feeders. Drifting fine particulate organic matter (FPOM), which has a particle size of less than $1.0 \mathrm{~mm}$ and comprises suspended solids such as periphyton and phytoplankton, is captured in the nets of these larvae, causing them to take in organic matter contaminated with radioactive Cs (Yoshimura and Akima 2014). In the study reported in the present paper, we evaluated the biological half-life of radioactive Cs in an excretion experiment and verified the residual ratio in the digestive tract, muscle, and extra-alimentary tissue of $S$. marmorata larvae.

\section{Materials and methods}

\section{Study site and sample treatment}

Between April 2013 and November 2015, larvae of S. marmorata and drifting FPOM were collected $1 \mathrm{~km}$ upstream (Mano-U) of the inlet and $5 \mathrm{~km}$ downstream (Mano-D) of the Hayama reservoir dam $\left(37^{\circ} 43.06^{\prime} \mathrm{N}, 140^{\circ} 49.58^{\prime} \mathrm{E}\right)$ on the Mano River, Fukushima Prefecture, Japan (Fig. 1). The annual precipitation at the dam site was $1248 \mathrm{~mm}$ in 2013, $1957 \mathrm{~mm}$ in 2014, and $1899 \mathrm{~mm}$ in 2015. The averages of the annual maximum and minimum temperatures of the river water for the last ten years were $22.7 \pm 2.5$ and $1.9 \pm 1.1^{\circ} \mathrm{C}$, respectively. The head of the Mano River basin is in an area of dense conifer and deciduous forest. At each sampling site, the river valley is steep, leading to considerable inflow of leaf litter. The gravel bed river channel width is about 5-10 $\mathrm{m}$, and emerged plants grow along the bank of the river. A bivoltine lifecycle with nonwintering and wintering generations was noted for $S$. marmorata.

Data were collected on April 23, May 21, July 2, August 30, and November 21 in 2013, January 9 in 2014, and May 2, July 29, and November 8 in 2015. During each collection, a lump of $S$. marmorata larvae was preserved in $95 \%$ ethanol and transported back to the laboratory in Saitama University. The head capsule lengths of the larvae were then measured and classified into final-instar groups under a dissecting microscope. After drying whole-body samples including the gut contents at $50{ }^{\circ} \mathrm{C}$ for $24 \mathrm{~h}$, their individual dry weights were measured to the nearest $0.1 \mathrm{mg}$ and confirmed using an electric balance (GR-120, A\&D, Tokyo, Japan). Each dried lump of larvae was ground and homogenized.

Drifting FPOM was collected using a net sampler $30 \mathrm{~cm}$ in diameter and with a mesh size of $100 \mu \mathrm{m}$ for $5 \mathrm{~min}$ to obtain five replicates (Ock and Takemon 2010). FPOM samples were classified into four size groups $(64-125,125-250$,

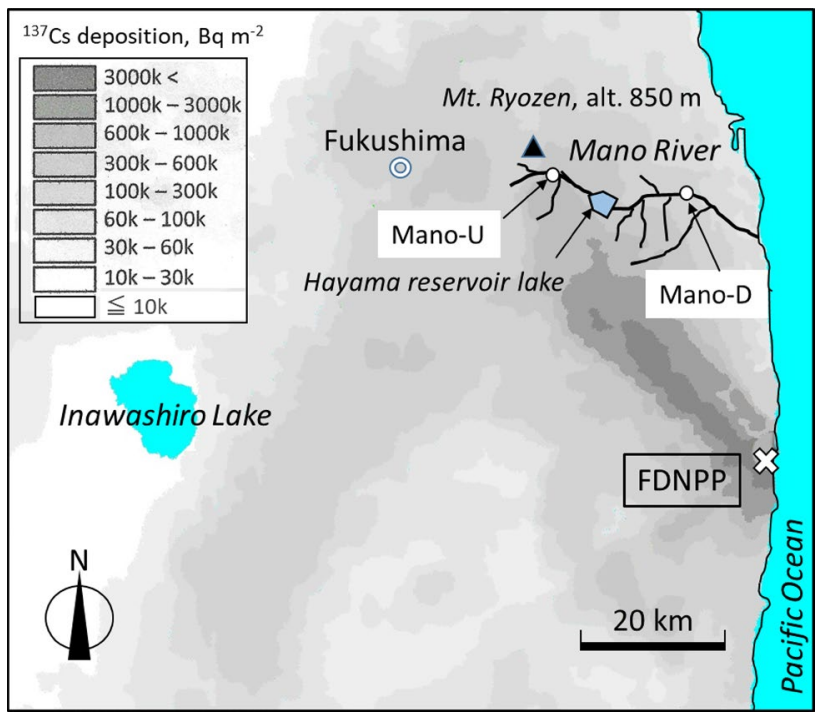

Fig. 1 Map of the Mano River basin and sampling sites (Mano$\mathrm{U}$ and Mano-D) in the present study, and the modified radioactive cesium (Cs-137) surface deposition distribution, based on data from the Fourth Airborne Monitoring Survey performed from October 22 to November 5, 2011 (MEXT 2011). FDNPP Fukushima Daiichi Nuclear Power Plant. a Nonwintering generation, b wintering generation

250-500, and 500-1000 $\mu \mathrm{m}$ ) by wet sieve analysis and dried at $110^{\circ} \mathrm{C}$ in an oven. The carbon content of the FPOM was analyzed using a CHN coder (MT-6, Yanaco, Kyoto, Japan).

\section{Intensive larvae collection for excretion experiments}

One lump of the final-instar larvae of the nonwintering generation (i.e., $N_{0}$ ) was collected and immediately preserved in 95\% ethanol on August 26, 2013 at Mano-D at a temperature of $20^{\circ} \mathrm{C}$. Another 200 larvae were collected at the site and kept alive in a tank with river water including trace amounts of suspended solids, and were then transported to the laboratory. The larvae were moved to four cylindrical containers that were $30 \mathrm{~cm}$ in diameter and filled with river water, which was used as rearing water. Each cylindrical container was placed on a magnetic stirrer to create a circular flow. The water temperature was maintained at the temperature of the river using a cool-water circulating device (CA-1116A, EYELA, Tokyo, Japan), and oxygen was supplied by an aerator (SA-1200S, KOTOBUKI, Tokyo, Japan). Collected larvae were divided into five lumps (i.e., $N_{1}-N_{5}$ ), and these lumps of larvae were preserved in $95 \%$ ethanol after 3, 6, 12, 24, and $48 \mathrm{~h}$, respectively, in order to evaluate the decreasing trend in radioactive $\mathrm{Cs}$ contamination during fasting. The same handling procedure as described above was performed for 9 lumps of larvae for the wintering generation (i.e., 
$\left.W_{0}, W_{1}-W_{8}\right)$ on December 5, 2013, when the temperature was $7{ }^{\circ} \mathrm{C}$. These lumps were fixed in cylindrical containers containing 95\% ethanol after 3, 6, 12, 24, 48, 72, 96, and $120 \mathrm{~h}$, respectively. Each lump contained between 18 and 21 individuals. The radioactive Cs concentrations in the lumps were analyzed and regression curves were then plotted and fitted by least-squares methods. The biological half-life of radioactive $\mathrm{Cs}$ in each season was determined using the SPSS ver.20 software package (IBM, Tokyo, Japan).

\section{Radioactivity measurement}

The radioactive Cs-134 and Cs-137 concentrations in $S$. marmorata larvae and drifting FPOM samples were measured using a germanium coaxial gamma-ray detector (EGC25-195-R, Canberra-Eurisys, Meriden, CT, USA) at Tokyo University of Agriculture and Technology. The energy and efficiency of this detector were calibrated using standard and blank (background) samples. For the analysis of radionuclide activity, each sample was measured until a $10 \%$ error count per net area count was reached (Sakai et al. 2015).

\section{Verification of the stable Cs residual ratio in the digestive tract and other parts of $S$. marmorata}

Other final-instar larvae of $S$. marmorata, drifting FPOM, and algae attached to the surfaces of stones were obtained from Arakawa River, Yorii Town, in Saitama Prefecture $\left(36^{\circ} 6.56^{\prime} \mathrm{N}, 139^{\circ} 13.11^{\prime} \mathrm{E}\right)$, where stable Cs contamination was observed. These samples were taken to the laboratory, where they were placed in a cylindrical container 30 $\mathrm{cm}$ in diameter, and a $10 \mathrm{mg} \mathrm{L}^{-1}$ stable Cs solution (Wako Chemicals Co. Ltd., Osaka, Japan) was added to the river water. The same system without the stable Cs was used as a blank. The FPOM was separated into $125-\mu \mathrm{m}$ and $64-\mu \mathrm{m}$ sizes, used in the test, and then kept for $72 \mathrm{~h}$ at $20^{\circ} \mathrm{C}$. Three larvae were removed and the digestive tract, muscle, and extra-alimentary tissue were carefully trimmed from each using small scissors. Then the scissors were inserted along the side of the body from the first abdominal section (near the posterior limb). Muscle and extra-alimentary tissue were discriminated by color and firmness. The other three individuals were moved to systems without contaminants and left to stand for a further $72 \mathrm{~h}$. The same treatment was conducted, and the quantity of stable Cs remaining in each body part of the individuals and the FPOM was measured by ICP-MS (iCAP Qc, Thermo Fisher Scientific Inc., Waltham, MA, USA).

\section{Results and discussion}

\section{Elimination of radioactive Cs in S. marmorata larvae}

The radioactive Cs-134 and Cs-137 concentrations after each fasting time for each lump of $S$. marmorata larvae (both the nonwintering and wintering generations) are shown in Table 1. The gut contents were included in the assessments for both generations. Cs-134 was not detected after $12 \mathrm{~h}$ of fasting in the tests. Cs-137 was detected up to $48 \mathrm{~h}$ of fasting in the nonwintering generation, at which point $20 \%$ of the initial Cs-137 remained in the larvae. In the wintering generation, Cs- 137 was detected up to $96 \mathrm{~h}$ of fasting, at which point $15 \%$ of the initial Cs-137 remained.

The two-compartment model used in a nickel concentration transfer investigation of $S$. marmorata by Tochimoto et al. (2003) was applied to highlight the attenuation trends in the Cs-137 values for each generation (Fig. 2). This modeling of the time course of toxicant disposition in the whole organism is to present the body as a system of plural compartments (Shen 2013). The larvae eliminated radioactive Cs rapidly during the first $6 \mathrm{~h}$ for the nonwintering generation and rapidly during the first $9 \mathrm{~h}$ for the wintering generation. The excretion of gut contents took longer in winter than in summer because of the lower temperature (Mizuno and Tanaka 1969; Tsuda 1975). The slow decrease in Cs- 137 concentration after 12-24 h appears to be due to the excretion of gut contents, because the radioactive Cs was obtained from FPOM. The total for the two compartments is close to the gut-emptying time for each generation of Stenopsyche spp. larvae, which is over $24 \mathrm{~h}$ according to an analysis by Tanida (2002) using data from Gose (1959) and Nishimura (1978). These results imply that most of the Cs-137 is not assimilated instantly by $S$. marmorata larvae because it is bound not only to the organic matter but also to fine-grained minerals (Motokawa et al. 2014; Tanaka et al. 2014). The calculated biological half-life of Cs-137 was $5.3 \mathrm{~h}$ in the nonwintering generation. In contrast, it was $8.8 \mathrm{~h}$ in the wintering generation. These half-life values are smaller than the first biological half-life of nickel from food, which is 1.4 days at $14.6{ }^{\circ} \mathrm{C}$, as reported by Tochimoto et al. (2003). The second biological half-life is 12.1 days, indicating that nickel remains in the body, and reflects the long time required to achieve a state of equilibrium. Our results from short interval tests show a clear trend for gut contents to be excreted over the course of a few days; however, a physiological interpretation of the difference between the two compartments is not readily apparent because they do not have exact correspondence to anatomical structure or physiological processes (Shen 2013). 
Table 1 Radioactive Cs concentration after each fasting time for each lump of Stenopsyche marmorata larvae (including gut contents)

\begin{tabular}{|c|c|c|c|c|c|}
\hline Lump & $\mathrm{TDW}^{\mathrm{a}}(\mathrm{gDW})$ & Fasting time (h) & $\begin{array}{l}\text { Cs-134 } \\
\left(\mathrm{Bq} \mathrm{kg}^{-1}\right)\end{array}$ & $\begin{array}{l}\text { Cs-137 } \\
\left(\mathrm{Bq} \mathrm{kg}^{-1}\right)\end{array}$ & $\begin{array}{l}\text { Cs- } \\
134+\mathrm{Cs}-137 \\
\left(\mathrm{~Bq} \mathrm{~kg}^{-1}\right)\end{array}$ \\
\hline
\end{tabular}

Nonwintering generation

$\begin{array}{lll}N_{0} & 2.03 & \\ N_{1} & 1.57 & \\ N_{2} & 1.62 & 12 \\ N_{3} & 1.05 & 24 \\ N_{4} & 1.11 & 48 \\ N_{5} & 1.04 & \end{array}$

Wintering generation

\begin{tabular}{llrlll}
$W_{0}$ & 1.03 & 0 & 521 & 1172 & 1693 \\
$W_{1}$ & 1.63 & 3 & 419 & 1012 & 1432 \\
$W_{2}$ & 1.41 & 6 & 297 & 668 & 965 \\
$W_{3}$ & 1.25 & 12 & 237 & 475 & 712 \\
$W_{4}$ & 1.09 & 24 & N.D. & 264 & 264 \\
$W_{5}$ & 1.53 & 48 & N.D. & 159 & 159 \\
$W_{6}$ & 1.58 & 72 & 32 & 56 & 88 \\
$W_{7}$ & 1.37 & 96 & N.D. & 48 & 48 \\
$W_{8}$ & 1.84 & 120 & N.D. & N.D. & N.D. \\
\hline
\end{tabular}

${ }^{\text {a }}$ TDW is the total dry weight of the lump

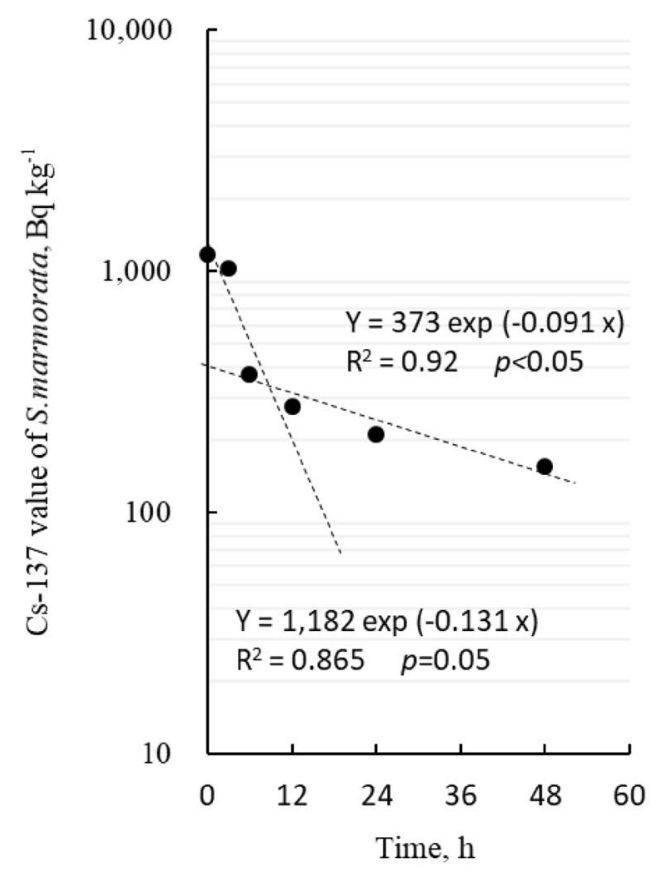

a non-wintering generation

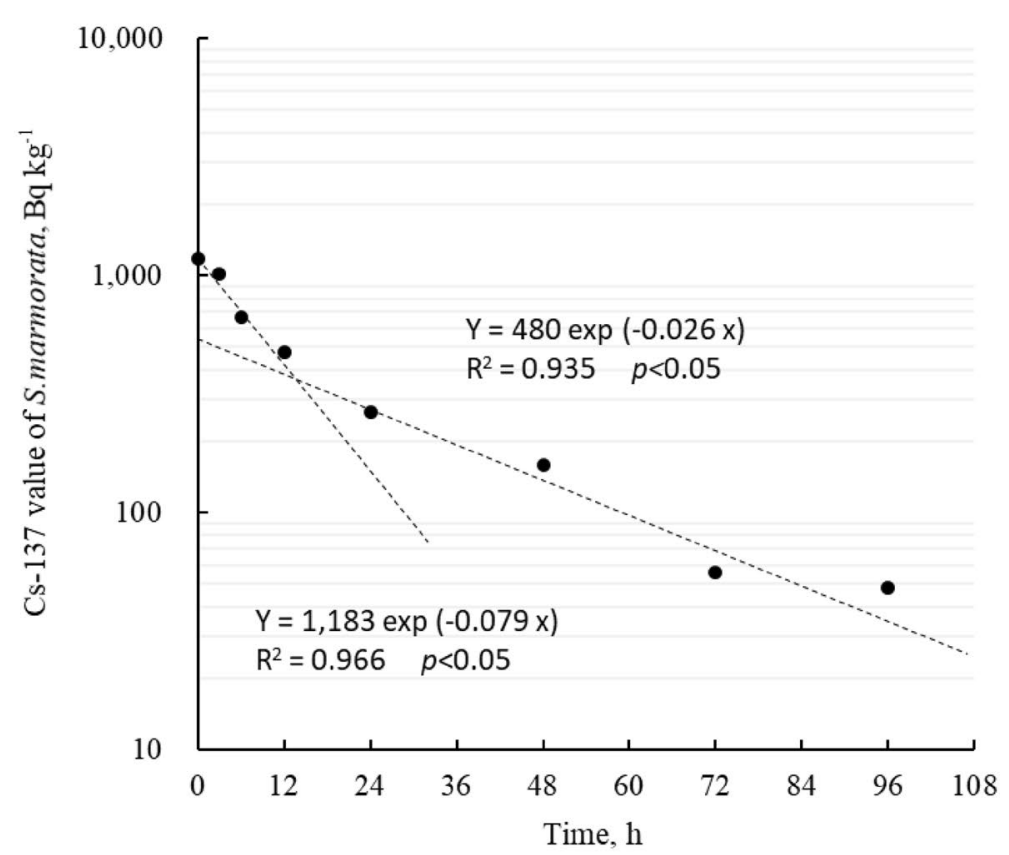

b wintering generation

Fig. 2 Results from the excretion experiments for radioactive Cs in each lump of Stenopsyche marmorata larvae (including gut contents)

\section{Residual stable Cs in the digestive tract and in extra-alimentary tissue}

The average stable Cs concentrations in the digestive tract, muscle, and extra-alimentary tissue of the $S$. marmorata larval body are shown in Fig. 3. The wet weights of the digestive tract, muscle, and extra-alimentary tissues per individual before excretion (i.e., immediately after the samples 


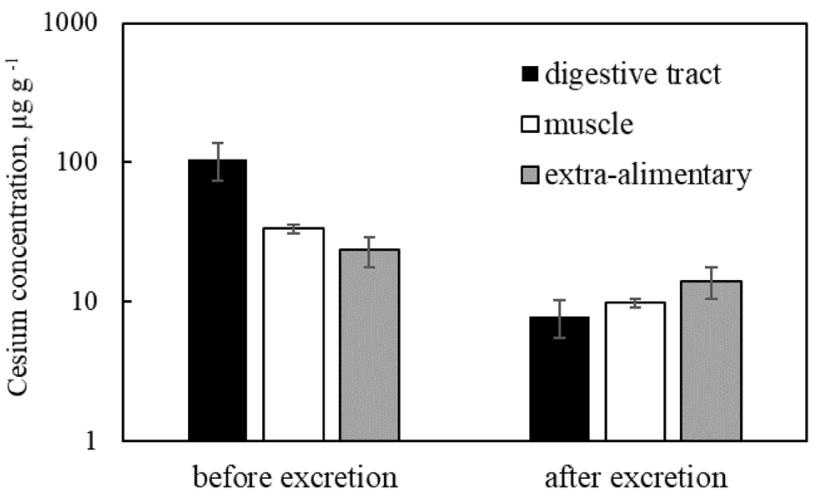

Fig. 3 The stable Cs concentrations in digestive tract, muscle, and extra-alimentary tissue of the fifth-instar larvae of Stenopsyche marmorata. Error bars refer to the S.E. $(n=3)$; before excretion: $72 \mathrm{~h}$ of immersion in a solution containing stable Cs; after excretion: $72 \mathrm{~h}$ of immersion in water without stable Cs after the immersion in a solution containing stable Cs

had been immersed in a solution containing stable Cs for $72 \mathrm{~h}$ ) were $49.0 \pm 20.9,2.1 \pm 0.9$, and $237.2 \pm 71.0 \mathrm{mg}$, respectively. Those per individual after excretion (i.e., after the samples had been moved to the system without stable Cs and immersed for another $72 \mathrm{~h}$ ) were $12.1 \pm 3.2,3.4 \pm 1.2$, and $188.8 \pm 53.9 \mathrm{mg}$, respectively.

The stable Cs concentration in the digestive tract was significantly higher $\left(105.4 \mu \mathrm{g} \mathrm{g}^{-1}\right)$ than those in the other parts of the larvae. The stable Cs concentrations in the $125-\mu \mathrm{m}$ and 64- $\mu \mathrm{m}$ suspended FPOM were 22.6 and $52.4 \mu \mathrm{g} \mathrm{g}^{-1}$, respectively. The stable Cs concentrations after excretion were decreased to just $7.5 \%$ of the original in the digestive tract, $29.3 \%$ of the original in muscle, and $60.1 \%$ of the original in the extra-alimentary tissue. In this experiment, two uptake processes of stable Cs-feeding on FPOM and infiltration of water-were considered. The observed rapid elimination of stable Cs from the digestive tract supports the results of on-site experiments. The ratio of muscle to total weight for $S$. marmorata larvae is very low, and most of the remaining stable Cs was found to occur in the extraalimentary tissue. It appears that these differences arise from the osmosis of dissolved stable Cs in the tissues of the larval body.

\section{Relationship of the radioactive Cs concentration in S. marmorata larvae to that in FPOM}

From 2013 to 2015, the annual peak value of the radioactive Cs concentration in drifting particulate organic matter of size $125-250 \mu \mathrm{m}$ (FPOM) was recorded during the rainy season (i.e., July-September). There was no clear decrease in the radioactive Cs concentration in $S$. marmorata larvae (STENO) during the 2 years of observations (Table 2). The ratio STENO/FPOM was generally less than 0.1 in 2013; however, it increased to 0.39 on May 2, 2015 for Mano-U and to 0.89 on November 8, 2015 for Mano-D. The carbon content of FPOM decreased from greater than $15 \%$ in 2013 to less than 5\% in 2015 at both sites. Upon performing excretion experiments in 2013, we found that most of the contaminants and food consumed passed through the digestive tract of the larvae without being assimilated into
Table 2 The radioactive $\mathrm{Cs}$ concentration in drifting fine particulate organic matter $125-250 \mu \mathrm{m}$ in size (FPOM) and in lumps of Stenopsyche marmorata larvae (STENO), the radioactive $\mathrm{Cs}$ concentration ratio STENO/FPOM, and the carbon content of FPOM at various dates

\begin{tabular}{lcllc}
\hline Date & $\begin{array}{l}\text { (1) Cs-134 + Cs-137 } \\
\text { in FPOM }\left(\mathrm{Bq} \mathrm{kg}^{-1}\right)\end{array}$ & $\begin{array}{l}\text { (2) Cs-134 + Cs-137 } \\
\text { in STENO }\left(\mathrm{Bq} \mathrm{kg}^{-1}\right)\end{array}$ & $\begin{array}{l}\text { (3) (1)/2) (i.e., } \\
\text { STENO/FPOM) }\end{array}$ & $\begin{array}{c}\text { Carbon content } \\
\text { of FPOM (\%) }\end{array}$ \\
\hline Mano-U site & & & & \\
April 23, 2013 & 22,160 & 3630 & 0.16 & 5.3 \\
May 21, 2013 & 28,320 & 1467 & 0.05 & 17.5 \\
July 2, 2013 & 29,500 & 1870 & 0.06 & 20.5 \\
August 30, 2013 & 59,700 & 5450 & 0.09 & 16.6 \\
November 21, 2013 & 39,500 & 2205 & 0.06 & 13.7 \\
May 2, 2015 & 6,705 & 2611 & $\mathbf{0 . 3 9}$ & 3.6 \\
July 29, 2015 & 10,450 & 2525 & $\mathbf{0 . 2 4}$ & 3.4 \\
Mano-D site & & & & \\
April 23, 2013 & 28,580 & 1267 & 0.04 & 14.7 \\
May 21, 2013 & 20,620 & 1356 & 0.07 & 23.3 \\
August 30, 2013 & 75,200 & 5580 & 0.07 & 7.7 \\
November 21, 2013 & 34,240 & 1991 & 0.06 & 9.2 \\
January 9, 2014 & 12,330 & 1068 & 0.09 & 15.0 \\
May 2, 2015 & 6337 & 650 & 0.10 & 6.8 \\
July 29, 2015 & 8099 & 1235 & $\mathbf{0 . 1 5}$ & $\mathbf{0 . 8 9}$ \\
November 8, 2015 & 3270 & 2898 & & \\
\hline
\end{tabular}

The number of individuals in each lump was between 20 and 30 
their bodies. The ratio of total body weight to digestive tract weight was 10:1 on a dry weight basis. The radioactive Cs concentration found in the larvae of $S$. marmorata reflected the Cs concentration in FPOM. The uptake of radioactive Cs in 2015 is thought to derive from ultrafine particulate matter such as suspended vermiculite clay (Motokawa et al. 2014).

Tanaka et al. (2014) reported that particles smaller than $125 \mu \mathrm{m}$ had higher radioactive Cs concentrations, reflecting their enhanced specific surface areas, but the contribution of the clay-size fraction (which had the highest Cs-137 concentration) was small because clay-size particles comprise only a very small fraction of the total volume of particles. The Forestry and Forest Products Research Institute (2014) reported that the proportion of radioactive Cs distributed in the soil surface layer $(<5.0 \mathrm{~cm})$ has increased year on year, reaching $77-86 \%$ of the total radioactive Cs in 2014. Sakai et al. (2016) reported that, the concentration in Cs-137 in stream litter is significantly lower than in forest litter resulting of Cs-137 reaching from litter in stream water in the early stage of the accident. The high Cs- 137 concentration in S. marmorata larvae in 2015 may have been due to particularly high contamination of the larvae with ultrafine (less than a few $\mu \mathrm{m}$ in diameter) particulate matter. A large amount of radioactive Cs deposition occurred; this correlates with the particulate Cs-137 concentrations in streams and rivers in Fukushima Prefecture (Tsuji et al. 2014). Further continuous monitoring and analyses of both $S$. marmorata and suspended solids should be carried out. In the field survey, we noted that the Hayama Reservoir tends to trap FPOM in the Mano River catchment. Much transported sediment has been trapped in the reservoir. However, radioactive Cs was deposited across the whole river catchment by the FDNPP accident, and the smaller size fraction of particulate matter still contains radioactive $\mathrm{Cs}$ at significant levels and worked as its carrier in the catchment.

Acknowledgements Invaluable comments that helped us to improve this manuscript were provided by the anonymous reviewers. The authors are grateful to Mr. Akihiro Yamada of Fukushima Prefecture for his help with the collection of $S$. marmorata samples in Mano River. A portion of this study was supported by a Grant-in-Aid for Scientific Research (C) (\#15K11954) from the Japan Society for the Promotion of Science.

Open Access This article is distributed under the terms of the Creative Commons Attribution 4.0 International License (http://creativecommons.org/licenses/by/4.0/), which permits unrestricted use, distribution, and reproduction in any medium, provided you give appropriate credit to the original author(s) and the source, provide a link to the Creative Commons license, and indicate if changes were made.

\section{References}

Aizawa S, Tsunoda A, Yasuda M, Tsunoda K, Itabashi H (2009) Concentrations of heavy metals in caddisfly larvae of the Tone River system and their seasonal variations. Bunseki Kagaku 58:273-285 (In Japanese with English summary)

Aoya K, Yokoyama N (1987) Life cycles of two species of Stenopsyche (Trichoptera: Stenopsychidae) in Tohoku District. Jpn J Limnol 48:41-53 (In Japanese with English summary)

Dudgeon D (1999) The zoobenthos: a systematic review. In: Tropical Asian streams-zoobenthos, ecology and conservation. Hong Kong University Press, Hong Kong, pp 389-392

Forestry and Forest Products Research Institute (2014) Report on 2014 survey result of radioactive material distribution in the forest. Forestry and Forest Products Research Institute, Tsukuba (In Japanese)

Gose K (1959) A note on the daily food-consumption of Parastenopsyche sauteri larvae (Trichoptera: Stenopsychidae). Ecol Entomol 8:58-59 (in Japanese)

Gose K (1970) Life history and instar analysis of Stenopsyche griseipennis. Jpn J Limnol 31:96-106 (in Japanese with English summary)

Katagami Y, Tanaka T, Honma T, Yokoyama A, Park HD (2004) Bioaccumulation of a cyanobacterial toxin, microcystin, on Stenopsyche marmorata and the ecological implications for its impact on the ecosystem of the Tenryu River, Japan. Jpn J Limnol 65:1-12 (In Japanese with English summary)

Matsuzaki K (2011) Validation trial of Japan's zinc water quality standard for aquatic life using field data. Ecotoxicol Environ Saf 74:1808-1823

MEXT (2011) Extension site of distribution map of radiation dose. Available at:http://ramap.jmc.or.jp/map/eng/. Accessed 1 July 2016

Ministry of the Environment, Japan (2015) Results of the FY2015 radioactive material monitoring survey of aquatic organisms. http:// www.env.go.jp/jishin/monitoring/result_ao160404-part/1-1.pdf and http://www.env.go.jp/jishin/monitoring/result_ao160404part/1-2.pdf. Accessed 1 July 2016 (in Japanese)

Mizuno T, Tanaka Y (1969) Food consumption of aquatic insects. Biological productivity of the Yoshino River Japan, vol 1. Research report of Nara Women's University, pp 12-20 (in Japanese)

Motokawa R, Endo H, Yokoyama S, Nishitsuji S, Kobayashi T, Suzuki S, Yaita T (2014) Collective structural changes in vermiculite clay suspensions induced by cesium ions. Sci Rep 4:6585

Nishimura N (1978) Ecological note on Stenopsychidae (Trichoptera) 1. Food consumption of 5th instar larvae. Hyogo Biol 7:171-173 (in Japanese)

Nishimura N (1984) Ecological studies on the net-spinning caddisfly, Stenopsyche marmorata Navas (Trichoptera: Stenopsychidae) 6. Larval and pupal density in the Maruyama River, central Japan, with special reference to floods and after-flood recovery processes. Physiol Ecol Jpn 21:1-34

Nozaki T, Saito R, Nishimura N, Hsu L-P, Tojo K (2016) Larvae and females of two Stenopsyche species in Taiwan with redescription of the male of $S$. formosana (Insecta: Trichoptera). Zootaxa 4121(4):485-494

Ock G, Takemon Y (2010) Estimation of transport distance of fine particulate organic matter in relation to channel morphology in tailwaters of the Lake Biwa and reservoir dams. Landsc Ecol Eng 6:161-169

Rainbow PS, Hildrew AG, Smitha BD, Geatchesd T, Luoma SN (2012) Caddisflies as biomonitors identifying thresholds of toxic metal bioavailability that affect the stream benthos. Environ Pollut 166:196-207

Sakai M, Gomi T, Naito RS, Negishi JN, Sasaki M, Toda H, Nunokawa M, Murase K (2015) Radiocesium leaching from contaminated litter in forest streams. J Environ Radioact 144:15-20

Sakai M, Gomi Negishi JN, Iwamoto A, Okada K (2016) Different cesium-137 transfers to forest and stream ecosystems. Environ Poll 209:46-52 
Shen DD (2013) Toxicokinetics. In: Klaassen CD (ed) Casarett \& Doull's toxicology: the basic science of poisons, chap 7, 8th edn. McGraw-Hill Education, New York, pp 367-390

Tanaka K, Iwatani H, Sakaguchi A, Takahashi Y, Onda Y (2014) Relationship between particle size and radiocesium in fluvial suspended sediment related to the Fukushima Daiichi Nuclear Power Plant accident. J Radioanal Nucl Chem 301:607-613

Tanida K (2002) Stenopsyche (Trichoptera: Stenopsychidae): ecology and biology of a prominent Asian caddis genus. In: Mey W (ed) Proceedings of the 10th International Symposium on Trichoptera. Antiquariat Geock \& Evers, Potsdam, pp 595-606

Tochimoto H, Maki T, Tanabe S (2000) Serial variations of trace metal concentrations in aquatic insect Stenopsyche marmorata. Toxicol Environ Chem 77:241-253
Tochimoto H, Maki T, Afzal M, Tanabe S (2003) Accumulation of trace metals in aquatic insect Stenopsyche marmorata Navas transferred in streams. Ecotoxicol Environ Saf 56:256-264

Tsuda M (1975) Productivity of communities in Japanese inland waters. In: Productivity of the Yoshino River, Nara. JIBP Synthesis vol 10. University of Tokyo Press, Tokyo, pp 339-377

Tsuji H, Yasutaka T, Kawabe Y, Onishi T, Komai T (2014) Distribution of dissolved and particulate radiocesium concentrations along rivers and the relations between radiocesium concentration and deposition after the nuclear power plant accident in Fukushima. Water Res 60:15-27

Yoshimura M, Akima A (2014) Radioactive contamination of aquatic insects in a stream impacted by the Fukushima nuclear power plant accident. Hydrobiologia 722:19-30 